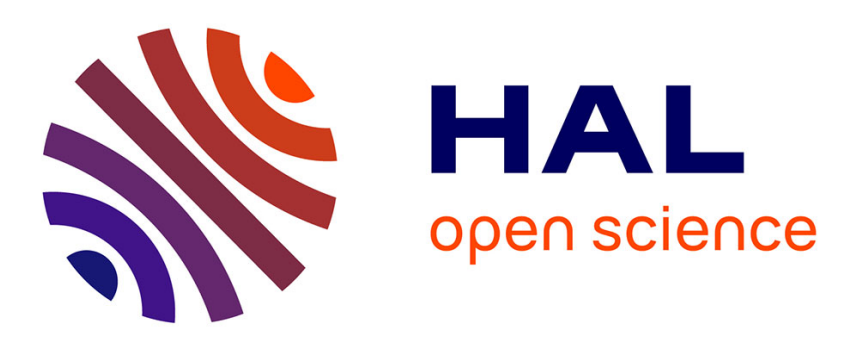

\title{
Financial return for government support of large-scale thin-film solar photovoltaic manufacturing in Canada
}

K. Branker, J.M. Pearce

\section{To cite this version:}

K. Branker, J.M. Pearce. Financial return for government support of large-scale thin-film solar photovoltaic manufacturing in Canada. Energy Policy, 2010, 38 (8), pp.4291-4303. 10.1016/j.enpol.2010.03.058 . hal-02120501

\section{HAL Id: hal-02120501 \\ https://hal.science/hal-02120501}

Submitted on 6 May 2019

HAL is a multi-disciplinary open access archive for the deposit and dissemination of scientific research documents, whether they are published or not. The documents may come from teaching and research institutions in France or abroad, or from public or private research centers.
L'archive ouverte pluridisciplinaire HAL, est destinée au dépôt et à la diffusion de documents scientifiques de niveau recherche, publiés ou non, émanant des établissements d'enseignement et de recherche français ou étrangers, des laboratoires publics ou privés. 
Financial Return for Government Support

\title{
of Large-Scale Thin-Film Solar Photovoltaic Manufacturing in Canada
}

\author{
K. Branker and J. M. Pearce* \\ Department of Mechanical and Materials Engineering, Queen's University \\ * Corresponding author: 60 Union Street, Kingston, Ontario, K7L 3N6 Canada, ph: 613-533-3369, \\ email: pearce@me.queensu.ca
}

\begin{abstract}
As the Ontario government has recognized that solar photovoltaic (PV) energy conversion is a solution to satisfying society's energy demands while reducing the adverse anthropogenic impacts on the global environment that compromise social welfare, they have begun to generate policy and funding programs to support financial incentives for PV. This paper provides a financial analysis for investment in a 1 GW per year turnkey amorphous silicon PV manufacturing plant. The financial benefits for both the provincial and federal governments were quantified for: i) full construction subsidy, ii) construction subsidy and sale, iii) partially subsidize construction, iv) a publicly owned plant, v) loan guarantee for construction, and vi) an income tax holiday. Revenues for the governments are derived from: taxation (personal, corporate, and sales), sales of panels in Ontario, and saved health, environmental and economic costs associated with offsetting coal-fired electricity. Both governments enjoyed positive cash flows from these investments in less than 12 years and in many of the scenarios both governments earned well over $8 \%$ on investments from 100 s of millions to $\$ 2.4$ billion. The results showed that it is in the financial best interest of both the Ontario and Canadian federal governments to implement aggressive fiscal policy to support large-scale PV manufacturing.
\end{abstract}

Keywords: financing; government incentives; photovoltaic 


\section{Introduction}

Anthropogenic climate destabilization as a result of the over consumption of polluting fossil fuels presents an immediate threat to human welfare, ecosystems and the economy (IPCC, 2008; Stern, 2007). Excessive carbon dioxide emissions from fossil fuel consumption for energy generation continue to cause irreversible damage to the global environment (Alley, et al., 2003) on which human welfare and the economy depends (Field and Olewiler, 2005). Sustainable and renewable energy technologies (RETs) such as solar photovoltaic (PV) energy conversion are a solution to satisfying society's energy demands while at the same time reducing the adverse anthropogenic impacts of fossil fuels (IEA, 2008; Sims et al., 2003). As it is becoming more clear that energy policy needs to be informed by life cycle carbon emissions (Kenny et al., 2010), many of the world's governments have produced policies intended to procure and improve the cost-effectiveness of RET projects by offering financial incentives (programs), such as the Feed-in Tariff (FIT), which has been implemented in over 64 jurisdictions (REN, 2009).

Ontario has made notable efforts towards expanding its RET sector. Although the 2009 and 2010 Federal budgets clearly indicate that the Canadian federal government is not directly investing or generating policy to support financial incentives for PV, it is providing funding for sustainable energy infrastructure to the provinces (DoF, 2009; 2010). In 2009, the Ontario Power Authority (OPA) launched the FIT program supported by the Green Energy and Green Economy Act 2009 (Smitherman, 2009) to procure RETs with small scale solar PVs receiving the highest tariff rate of $80.2 \mathrm{\$} / \mathrm{kWh}$ (OPA, 2009). In 2010, the Ontario government signed a \$ 7 billion agreement between and Samsung C\&T Corporation and the Korea Power Electric Corporation (KPEC) which includes both solar PV and wind manufacturing facilities (Ontario, 2010). Thus, the Ontario government is actively pursuing agreements with RET companies to stimulate manufacturing in Ontario. 
Solar PV is known to be a technically viable RET that can play a significant role in the sustainable development of the energy sector globally (Pearce, 2002). Although the FIT initiative is able to spark growth of the Ontario PV industry, the current subsidy structure does not guarantee grid parity and may lose many benefits associated with large-scale PV manufacturing for Canada. It is well established that in order to produce electricity from commercially-available PV technology at economically competitive rates compared to the currently highly subsidized energy sector, the manufacturing capacity of PV must be enlarged (Kumar et al., 2007; Pearce, 2008). Whilst governments continue to prepare and establish energy policy to incentivize the growth of RETs, it is important to know that benefits arising from these initiatives are maximized for society and the environment. To further this goal, this paper examines the potential return and benefits from various types of government investment in large-scale thin film PV manufacturing in Ontario, Canada. The benefits are assessed based on the financial impact generated by the PV manufacturing business.

\section{Background on Photovoltaic Technology}

The solar industry is expected to continue to see massive growth as new manufacturing concepts, improved understanding of solar materials and standardized turnkey production allows scaling up of production with associated decreases in costs (Kumar et al., 2007; Rentzing, S. 2007; VLSI Research Inc., 2009). The Ontario FIT program is poised to increase demand in Canada, whilst Canada currently only manufactures PV in small quantities. Importing large capacities of PV from other countries will direct the incentives to subsidizing other economies - a market that Canada could capitalize on for itself when the growth of the PV market in Canada has been averaging 25\% annually since 1993 (Ayoub, 2006). Using simple economic theory, Fig. 1 illustrates that increasing the quantity $\left(\mathrm{Q}_{0}\right.$ to $\left.\mathrm{Q}_{1}\right)$ of solar deployed in the market whilst lowering the price $\left(\mathrm{P}_{0}\right.$ to $\left.\mathrm{P}_{1}\right)$ requires both and 
increase in demand (D) (i.e. by improving access to financing or improving PV efficiency and thus life cycle costs) and supply (S) (i.e. by increasing manufacturing).

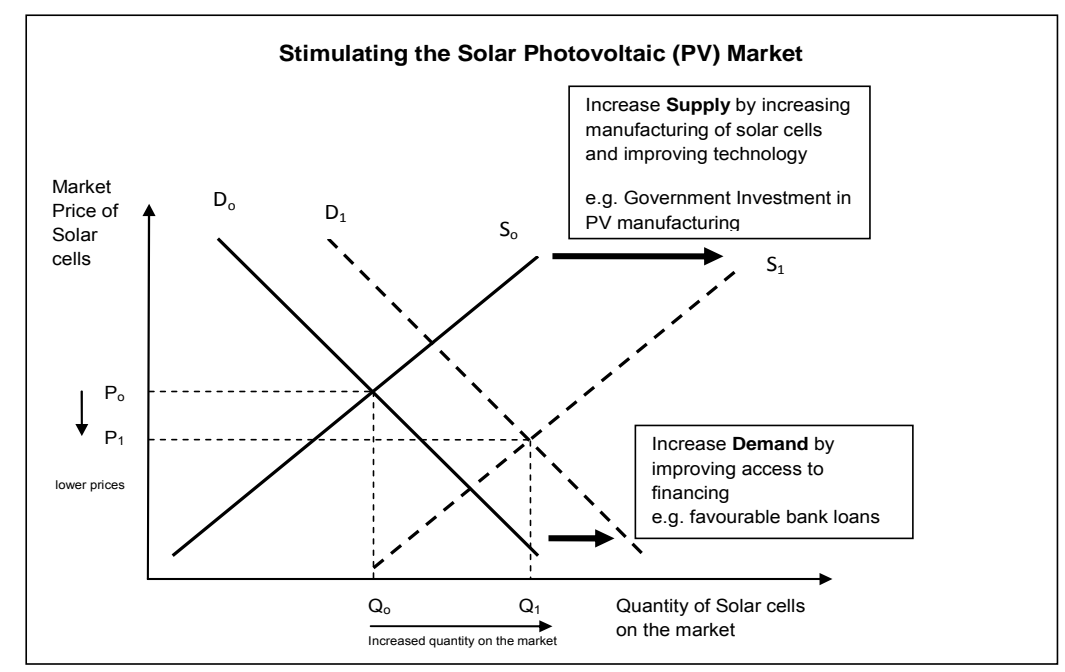

\section{Figure 1: Simple supply and demand schematic for growing the PV sector.}

The most aggressive growth has been seen in the thin film PV production, which grew by $123 \%$ in 2008 to reach $0.89 \mathrm{GW}$ (SolarBuzz, 2009). Although there is some evidence that thin film technologies such as amorphous silicon (a-Si) have a superior energy yield per installed unit power in regions with a large fraction of diffuse light (such as Canada) via their superior spectral response in the 400-500 nm region of the spectrum (Eikelboom and Jansen, 2000; Jardine, et al., 2001), reduced manufacturing costs (thus shifting S right in Fig. 1) still provide thin films their primary advantage over crystal silicon based technologies. Highly scalable thin film PV manufacturing uses deposition on monolithic large-area $\left(>1 \mathrm{~m}^{2}\right)$ inexpensive substrates like glass, or are deposited roll to roll on metal sheets and plastic films. The major growth in thin film PV can also be attributed to improved scientific understanding of thin film solar materials and technology (Collins et al., 2003, Ferlauto et al., 2004) and the trend of turnkey thin film facilities with standardized automated technology which allows for a multiplication effect in production with easy scalability in capacity, reduced ramp up times and rapid spread of technology and best practices (VSLI Research Inc, 2009). The success of the multiplication 
Published as: K. Branker and J. M. Pearce, "Financial Return for Government Support of Large-Scale Thin-Film Solar Photovoltaic Manufacturing in Canada”, Energy Policy 38, pp. 4291-4303 (2010).

http://dx.doi.org/10.1016/j.enpol.2010.03.058

effect in the thin film a-Si based turnkey facilities is supported by the experience and established skill sets of multinational corporations with track records in semiconductor and equipment manufacturing industries. Several studies indicate that a single large thin film a-Si turnkey fabrication facility (fab) on the scale of producing $1 \mathrm{GW}$ of PVs per year can reach grid parity (Keshner and Arya, 2004; Pearce, 2008). Approaching grid parity will enable growth even after subsidies and incentives are eliminated (Kumar et al., 2007). To invest in such a facility would require $\$ 2 / \mathrm{W}$ for the primary $1 \mathrm{GW} /$ year production line in addition to infrastructure investment of approximately $\$ 400$ million for a total cost of \$2.4 Billion (\$CAD) (Weinzerl, 2009). There is a track record of success in turn key facilities and it is expected that such a facility would drive down the costs from a current several dollars per $\mathrm{W}$ to well under \$1/W (Kumar et al., 2007).

Even though solar cells are installed locally, their manufacture can occur almost anywhere. This means that low cost manufacturing countries and those with fiscal incentives (e.g. tax holidays) in places such as Malaysia tend to dominate the market. However, in the case of thin film solar PV, with its fully automated standardized technology in turnkey facilities, countries with high taxation and labour costs may be able to become globally competitive if they can compensate with supportive public policy that provides tax credits for capital investment; research, development and technical training; and additional funding support beyond loan guarantees (Babinet et al., 2009).

Solar companies are taking advantage of government incentives with regards to choosing the location of their operations. In 2007, the Renewable Energy Corporation (REC) chose Singapore out of 200 locations for a $1.5 \mathrm{GW}$ solar Si wafer based manufacturing complex. The combination of tax incentives, grants, and a skilled workforce were some of the advantages for REC to choose Singapore (Faithful and Gould, 2007). Singapore is significantly smaller than Canada and will house the largest solar manufacturing complex in the world. Canada is poised to take advantage of the scalability and 
easy ramp up of thin film, a competitor to wafer based technology. Table 1 compares the facility size of a $1 \mathrm{GW}$ thin film fab with the $1.5 \mathrm{GW}$ wafer complex, using the General Motors factory in Ontario for comparison. This demonstrates that facility size and logistics are reasonable for Canada. Currently Canada's PV industry is in its infancy, but many companies are considering some form of assembly or manufacturing in Ontario to comply with the FIT domestic content restrictions (OPA, 2009). In 2010,the \$7 Billion (\$CAD) agreement between the Ontario government, Samsung C\&T Corporation and the KPEC was spurred on by the stability ensured by the FIT program (Ontario, 2010). Again, the choice of incentive should maximize benefits and minimize costs to society.

Table 1: Comparison of Facility Size

\begin{tabular}{rlccc}
\hline \multicolumn{1}{c}{ Plant/ Facility type } & Location & Capacity & $\begin{array}{c}\text { Size } \\
\left(\mathrm{m}^{2}\right)\end{array}$ \\
\hline 1) & Thin film manufacturing fab (estimated) & $\begin{array}{c}\text { Ontario } \\
\text { (proposed) }\end{array}$ & $1 \mathrm{GW}$ & 75,000 \\
2) & Integrated solar manufacturing complex (wafer) & $\begin{array}{c}\text { Tuas South, } \\
\text { Singapore } \\
\text { Oshawa, Ontario, } \\
\text { Canada }\end{array}$ & $\begin{array}{c}1.5 \mathrm{GW} \\
\text { vehicles/year }\end{array}$ & $\begin{array}{c}10,400,000 \\
\text { 3) }\end{array}$ \\
$\begin{array}{l}\text { Sources: } \\
\text { 1) }\end{array}$ & & & \\
2) & Faithful and Gould, 2007 & & \\
3) & Rosen, 2008 & & \\
\hline
\end{tabular}

\section{Impact of Large Scale Thin Film Photovoltaic Manufacturing and Job Creation}

The major impact of a $1 \mathrm{GW}$ fab's scale apart from economies of scale is benefits that include: i) stimulated local economic growth, ii) local job creation, iii) potential carbon dioxide offsets from installation of the produced solar PVs, iv) government revenue generation, v) avoiding environmental pollution costs, and vi) avoiding import costs for PV panels (Hayami and Nakamura, 2007; Pollin and Peltier, 2009; Schachter, 1979; Stoddard et al., 2006, Taylor et al., 2005). Job creation will be discussed in this section as a direct effect of the plant and the other benefits will be discussed and quantified in Sec. 4.

\subsection{Job Creation}


Published as: K. Branker and J. M. Pearce, "Financial Return for Government Support of Large-Scale Thin-Film Solar Photovoltaic Manufacturing in Canada”, Energy Policy 38, pp. 4291-4303 (2010).

http://dx.doi.org/10.1016/j.enpol.2010.03.058

Any economic activity has direct, indirect and induced job creation (Pollin and Peltier, 2009;

Stoddard et al., 2006). Direct jobs include those individuals employed in activities directly related to the plants activities. Indirect jobs include secondary jobs created by the addition of PV panels on the market, such as retailers and installers. Lastly, induced jobs occur when those directly and indirectly employed by RET projects then spend on other goods and services. Each job type also has full-time and part-time components. For this analysis, only direct and indirect jobs with full-time full-year components were estimated.

To quantify job creation, the installation of a $1 \mathrm{GW}$ turnkey fab project can be broken up into the construction phase and the operation phase. During the construction phase, temporary workers are employed locally to install the equipment and prepare the infrastructure for the plant. There is a direct economic impact due to those goods and services utilized from the local region for a project (Pollin and Peltier, 2009; Stoddard et al., 2006). The indirect impacts would then be the increased economic activity for local vendors as a result of the project (Stoddard et al., 2006). The beginning part of the operation phase is a ramp up phase during which the manufacturing lines are optimized and material logistics finalized. During the ramp-up phase, the production capacity of the plant increases incrementally and permanent plant jobs commence. Once the ramp up is completed, production at capacity begins. During the operation phase, the major economic impact is due to permanent jobs, but also includes annual purchases of goods and services for plant operations and maintenance (Pollin and Peltier, 2009; Stoddard et al., 2006). For this analysis, it is assumed that the construction phase of the facility will be two years and the ramp up period will be one year. ${ }^{2}$

Wei et al. (2010) note the discrepancy in classifying and reporting job creation from RET studies, but conclude in their study that solar PVs create the most jobs per electricity output unit. In the U.S., Wei et al. (2010) estimate that the on average 0.87 total job-years per GWh (26 jobs per MWp) 
Published as: K. Branker and J. M. Pearce, "Financial Return for Government Support of Large-Scale Thin-Film Solar Photovoltaic Manufacturing in Canada”, Energy Policy 38, pp. 4291-4303 (2010).

http://dx.doi.org/10.1016/j.enpol.2010.03.058

are created by solar PV compared to 0.11 total job-years per GWh for coal (8.7 jobs per MWp).

Schachter (1979) concludes that solar PV creates 55-80 times as many direct jobs as natural gas. Yet another study estimated 22.4 jobs per MW of solar PV which included component manufacturing in the U.S. (Gordon et al., 2007). Although there are variable estimates and reports on job creation as a result of investment in solar PV technology in different geographies (EPIA, 2008; Gordon et al., 2007), the report by Pollin and Peltier (2009) that estimates the job creation for green energy investments in Ontario is most fitting. Without considering manufacturing, Pollin and Peltier (2009) estimated that investment in the solar industry in Ontario, Canada creates 15.8 jobs per $\$ 1$ million with an estimated wage rate to be above $\$ 20$ per hour for most jobs. Thus as a conservative estimate, the average wage rate of $\$ 20$ per hour will be used. If it is assumed that the plant sells panels at $\$ 2 / \mathrm{W}$, then $\$ 1$ million is equivalent to 0.5 MW. This is used to normalize the 15.8 jobs per million to 31.6 jobs/ MW. For the analysis, the indirect job creation during operation and ramp up was considered to be $90 \%$ of the 31.6 jobs/ MW. This was directly scaled for the $1 \mathrm{GW}$ since these jobs would be dispersed all over Ontario, but considered $10 \%$ less to recognize diminishing returns to scale.

Estimates for a $150 \mathrm{MW}$ fab from Oerlikon Solar ${ }^{1}$, a large a-Si-based solar cell turnkey provider, were used to determine both the direct jobs created at a $1 \mathrm{GW}$ plant and the constructions jobs from building it. In order to eliminate any errors introduced from scaling up Oerlikon's estimates, a reduction factor of $22 \%$ less than direct scaling for smaller plant was used, providing 1,778 permanent direct jobs at the plant. This factor was created by considering only a doubling of overhead staff, management and miscellaneous positions whilst scaling operators, technicians and engineers by 7 times the smaller plant. This eliminated redundant positions necessary to cover round the clock operation in an attempt to be more conservative and efficient in the estimates. Similarly, the construction jobs, both direct and indirect were considered to be $10 \%$ less than direct scaling. Total jobs created instead of net 
Published as: K. Branker and J. M. Pearce, "Financial Return for Government Support of Large-Scale Thin-Film Solar Photovoltaic Manufacturing in Canada”, Energy Policy 38, pp. 4291-4303 (2010).

http://dx.doi.org/10.1016/j.enpol.2010.03.058

jobs created by the $1 \mathrm{GW}$ PV plant are utilized, although future economic analysis methodology will estimate this (Wei et al., 2010). Note however that jobs will be lost as the government of Ontario continues its plans to phase out coal-fired facilities by 2014 (Pollin and Peltier, 2009), with four more units planned to come offline in October 2010 (Office of the Premier, 2009).\{footnote this\}[Office of the Premier of Ontario, 2009. McGuinty Government Progress Report - Energy, Available at http://www.premier.gov.on.ca/progress/en/energy.asp] Table 2 summarizes the job creation estimates for the $1 \mathrm{GW}$ plant in Ontario assuming the project begins at the end of 2009 as an example. It should be noted as a limitation that the reduction in workers with automation and technological change (Wei et al., 2010) and any change in wage were not considered. However, a sensitivity analysis was conducted in Sec. 5 to investigate the effect of changes in these variables.

Table 2: Jobs created from a 1GW PV plant

\begin{tabular}{cccccc} 
& & & \multicolumn{3}{c}{ Jobs } \\
\cline { 3 - 6 } Year & Year & Phase & direct & indirect & total \\
\hline 2009 & 0 & Construction & 900 & 20 & 920 \\
2010 & 1 & Construction & 900 & 20 & 920 \\
2011 & 2 & Ramp Up & 1778 & 28440 & 30218 \\
2012 & 3 & Operation & 1778 & 28440 & 30218 \\
2013 & 4 & Operation & 1778 & 28440 & 30218 \\
2014 & 5 & Operation & 1778 & 28440 & 30218 \\
2015 & 6 & Operation & 1778 & 28440 & 30218 \\
2016 & 7 & Operation & 1778 & 28440 & 30218 \\
2017 & 8 & Operation & 1778 & 28440 & 30218 \\
2018 & 9 & Operation & 1778 & 28440 & 30218 \\
2019 & 10 & Operation & 1778 & 28440 & 30218 \\
$\ldots$ & $\ldots$ & $\ldots$ & $\ldots$ & $\ldots$ & $\ldots$ \\
\hline
\end{tabular}

The resulting job creation and economic activity of the plant and distributors means additional income tax revenue for the government. The other benefits aforementioned also have a contribution to government revenue, and will be quantified in Sec. 4 . 


\section{Government Revenue Streams for a Large Scale Thin Film PV Manufacturing Plant in}

\section{Ontario, Canada}

To estimate the revenue (retained income) streams for the government of i) taxation, ii) sales of panels in Ontario, iii) carbon offsets, and iv) saved health, environmental and economic (HEE) costs associated with offsetting coal-fired energy generation each year, several assumptions were made to simplify the analysis and are justified appropriately. To account for variability and uncertainty that could occur with certain input values, a single variable sensitivity analysis was done to gain the effect of changes in major variables. Values in all analysis were chosen conservatively.

\subsection{Methodology and Input Estimation}

Various input values needed to be collated or estimated before approximating the revenue streams for the government before performing the financial analysis.

\subsubsection{Taxation}

The major government revenue generator is taxation (DoF, 2009; StatCan, 2009). Several programs and subsidies consider the economic impact and government revenue in addition to social aims as justification for funding the programs (PHA, 2009; Taylor et al., 2005; WEDC, 2008). For taxation in Canada, personal income tax (PIT) accounts for the largest portion of government revenue (50\%), followed by corporate income taxes (CIT) (17\%) and goods and services tax (12\%) (DoF, 2009). In the analysis, the Federal government (Canada) and provincial government (Ontario) revenues were considered separately for only these three types of taxation. The Canada Revenue Agency (CRA, 2009) and OECD Tax database (OECD, 2009) were used to estimate the tax rates for PIT, CIT and sales in Canada and Ontario for 20 years. It is expected that some rates will change from the base case due to the dynamic nature of tax policy and fiscal initiatives. The chosen tax rates are summarized in 
Published as: K. Branker and J. M. Pearce, "Financial Return for Government Support of Large-Scale Thin-Film Solar Photovoltaic Manufacturing in Canada”, Energy Policy 38, pp. 4291-4303 (2010).

http://dx.doi.org/10.1016/j.enpol.2010.03.058

Table 3. The tax rate was assumed constant for subsequent years from the last available recorded number.

Table 3: Chosen Tax rates for the analysis

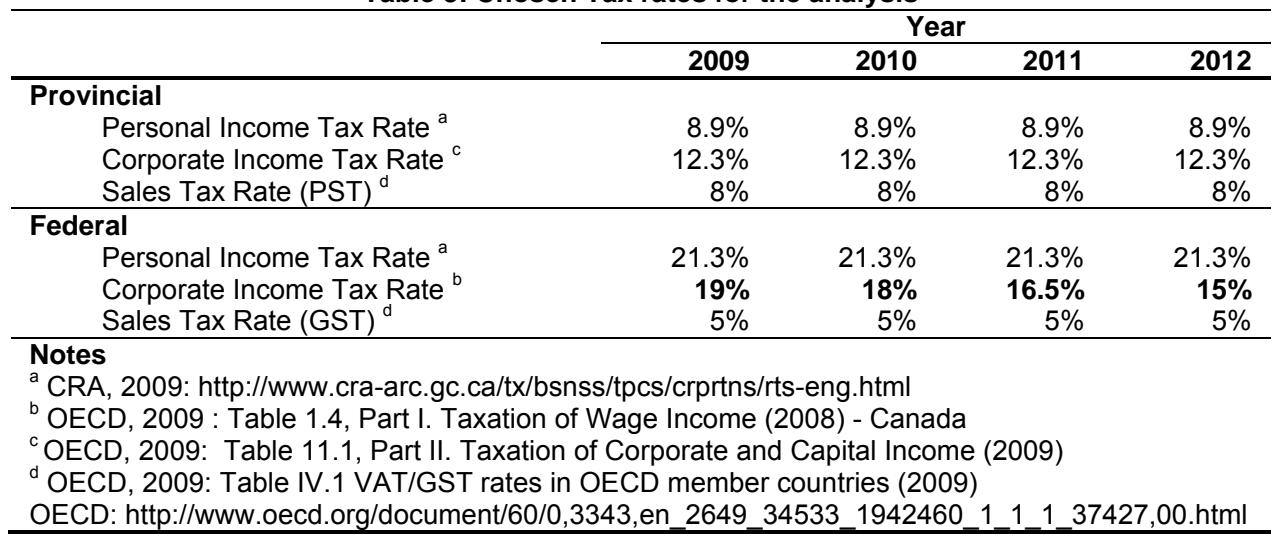

The tax rates were then used to estimate the government revenue generated by the installation of a 1 GW Solar PV manufacturing facility through job generation (in Sec. 3) and panel sales (CIT and wholesale sales tax). Deductions and credits were not accounted for.

\subsubsection{Sales of Panels to Ontario}

It is assumed that the market clears the entire $1 \mathrm{GW}$ of panels produced each year in Ontario alone, excluding the effect of exports. Ontario has more than $30 \mathrm{GW}$ of viable solar area potential on rooftops (Wiginton, et al., 2010), and over $90 \mathrm{GW}$ of potential for ground based solar farms on marginal land in south-eastern Ontario alone (Nguyen and Pearce, 2010) making this a feasible assumption. Further analysis could consider more detailed market research in conjunction with multiple plant deployments. A \$1/ W profit margin is assumed. As indicated in Sec. 2, the manufacturing cost is assumed to be $\$ 1 / \mathrm{W}$ even though companies worldwide have been able to achieve lower numbers (e.g. First Solar, 2009). This gives a wholesale price of $\$ 2 / \mathrm{W}$. 


\subsubsection{Carbon Dioxide Offsets}

Hayami and Nakamura (2007) conclude that PV technology is one of the most promising technologies to reduce carbon dioxide $\left(\mathrm{CO}_{2}\right)$ emissions from power generation. As a simple estimate from RETScreen4, every $1 \mathrm{~kW}$ of solar panels installed in Ontario would reduce $\mathrm{CO}_{2} \mathrm{emissions}$ by 0.27 tonnes per year or selling $1 \mathrm{GW}$ of panels equates to 270,000 tonnes of $\mathrm{CO}_{2}$ reduced per year ${ }^{3}$. Note that this estimate is based on a basic roof ${ }^{4}$ in Kingston, Ontario. There are already plans to phase out coal-fired power generation in Ontario by 2014 (Pollin and Peltier, 2009), but this analysis does not consider phasing out or removing coal-fired station, but offsetting the energy produced by assuming the energy produced by the solar panels replaces the coal generated energy, which is $73 \%$ of the fossil fuel based electrical power in Ontario (CEA, 2009b). This is feasible since the single plant is unable to completely offset all the emissions of the current grid energy mix.

\subsubsection{Health, Environmental and Economic (HEE) Costs of air pollution and $\mathrm{CO}_{2}$}

The price paid for energy produced by fossil fuels does not include the cost to the health system due to the associated air pollution, the cost of restoring damaged ecosystems and lost benefit of biodiversity and ecosystem services, and, the economic loss from reduced productivity due to illness caused by air pollution and early mortality (Taylor, et al., 2005). Government subsidizes the health and infrastructural sector such that pollution costs are directly related to government expenditure (Taylor, et al., 2005). Thus investing in carbon and air pollution offsetting activities would provide revenue savings for the government. Several studies exist that have assessed the health, economic and environmental costs associated with air pollution in Ontario and Canada (Boyd and Genuis, 2008; CMA, 2008; DSS 2005; OMA, 2005). In Ontario and Canada, roughly $25 \%$ of electrical production is 
Published as: K. Branker and J. M. Pearce, "Financial Return for Government Support of Large-Scale Thin-Film Solar Photovoltaic Manufacturing in Canada”, Energy Policy 38, pp. 4291-4303 (2010).

http://dx.doi.org/10.1016/j.enpol.2010.03.058

from coal or other fossil fuels (CEA, 2009a) which account for most of the air emissions from electric power generation (CAO, 2009).

DSS Management Consultants and RWDI Inc. conducted a detailed cost-benefit analysis (CBA) of the financial costs and health and environmental damages associated with replacing all of Ontario's coal-fired generating facilities (2005). It was estimated that the health and environmental damages associated with coal was $\$ 126.28$ / $\mathrm{MWh}^{5}$.The health impacts considered the effect of air quality on premature deaths, hospital admissions, emergency room visits and minor illness cases. Also included in the cost is the loss of productivity due to premature death and increased illness. Environmental damages include economic damage estimates relating to the soiling of household materials, crop loss and greenhouse gas emissions, and, potential costs for greenhouse gas control and permit purchasing. The study is limited to risks associated with ground-level ozone $\left(\mathrm{O}_{3}\right)$ and particulate matter (primarily PM 2.5 microns) which underestimated the health effects discussed in other studies (CMA, 2008; OMA, 2005). Similar studies considered the effect of air pollution in Ontario (OMA, 2005) and Canada (CMA, 2008) using similar methodology for health and associated economic impact assessment. For this analysis, the cost burden is assumed to be borne by the Ontario government as health care is subsidized and any loss of economic activity or additional costs to consumers or businesses to pay for dealing with environmental effects reduces the income tax revenue that could be generated. Although this would also affect the Federal government, this analysis accrues all of the burden and effect on the provincial government for simplicity, with the caveat that theFederal government transfers funding to the Provinces. This assumption means that the solar energy produced by the manufactured and installed solar PVs would offset the associated $\mathrm{CO}_{2}$ and air pollution produced by the coal and its associated cost, had it been used to produce that energy, ignoring latency effects. Currently, Ontario produces 28 TW-hr per year of energy from coal (CEA, 2009b). One GW of 
Published as: K. Branker and J. M. Pearce, "Financial Return for Government Support of Large-Scale Thin-Film Solar Photovoltaic Manufacturing in Canada”, Energy Policy 38, pp. 4291-4303 (2010).

http://dx.doi.org/10.1016/j.enpol.2010.03.058

solar PVs functioning for an average of 3 'peak sun hours' per day for a year would produce 1,095,750

MW-hr ( 1.1 TW-hr) in Ontario ${ }^{6}$. Currently, more than 25 years of cumulative deployment of $1 \mathrm{GW}$

of PVs would be required to replace electricity production by coal plants. This means that greater

deployment rates are necessary to replace coal and the cumulative market absorption of $1 \mathrm{GW}$ per year

of PV panels for 20 years in this analysis cannot displace all coal, validating the previous assumption to

consider only a coal offset. It is also clear that to eliminate all coal in the next 5 years in Ontario there

needs to be aggressive investment in RETs.

\subsubsection{Calculating Revenue Streams and Investment Returns}

Table 4 summarizes the symbols and variables used in the equations derived below, where upper case

letters are totals or aggregates and lower case are individual amounts. The equations were used to

evaluate the scenarios for the federal and provincial government separately. \{Table revised..update

separate file with tables before resubmit\}

Table 4: Summary of Symbols and Variables

\begin{tabular}{|c|c|c|c|}
\hline Symbol & Meaning & Symbol & Meaning \\
\hline$\pi$ & Profit rate on $\mathrm{PV}$ panels $(\$ 1 / \mathrm{W})$ & $n$ & Year, n (subscript or index on variables) \\
\hline$S_{n}$ & Total PV Sales Cost (for year "n") & $s_{n}$ & PV sales cost rate $(\$ 2 / \mathrm{W})$ \\
\hline$M_{n}$ & Total PV manufacturing cost & $m_{n}$ & PV manufacturing cost rate $(\$ 1 / \mathrm{W})$ \\
\hline$P_{n}$ & Total personal annual income & $p_{n}$ & Individual personal annual income \\
\hline$Q$ & Number of PVs sold/ supplied & $J$ & Number of jobs \\
\hline$g$ & $\begin{array}{l}\text { Total energy growth rate }=1.3 \% \text { for } \\
\text { Ontario (NEB, 2007) }\end{array}$ & $C_{n}$ & Corporate Income \\
\hline$T_{P, n}$ & Personal tax revenue & $t_{P, n}$ & Personal tax rate \\
\hline$T_{C, n}$ & Corporate tax revenue & $t_{C, n}$ & Corporate tax rate \\
\hline$T_{S, n}$ & Sales tax revenue & $t_{S, n}$ & Sales tax rate \\
\hline$H_{n}$ & Revenue from HEE & $h_{n}$ & HEE cost rate $=\$ 126.28 / \mathrm{MW}-\mathrm{hr}$ \\
\hline$E$ & $\begin{array}{l}\text { Total Solar Energy Generated in Ontario for } \\
1 \mathrm{GW} P V=1,095,750 \mathrm{MW}-\mathrm{hrs}^{6}\end{array}$ & $C_{i n, n}$ & Cash inflows for year "n" \\
\hline$C_{\text {out }, n}$ & Cash outflows for year " $n$ " & $C_{n e t}$ & Net Cash flow for year "n" \\
\hline$I R R$ & Internal rate of return of investment & $N_{P C F}$ & $\begin{array}{l}\text { Payback Period } \\
\text { (Years to Positive (Net) Cash Flow (PCF)) }\end{array}$ \\
\hline
\end{tabular}

The individual personal annual income is calculated as follows, estimating \$20/hour, a 40 hour week and a 50 week year:

$$
p_{n}=\text { Wage }_{\text {annual }}=\text { Wage }_{\text {hourly }} \times \text { work-hours / year }=\$ 40,000 / \text { year }
$$


The total personal annual income can then be calculated using the number of jobs, J:

$$
P_{n}=p_{n} \times J
$$

The total manufacturing cost is

$$
M_{n}=m_{n} \times Q
$$

and the total sales cost is simply:

$$
S_{n}=S_{n} \times Q
$$

The corporate income is the total profit generated by sale of $1 \mathrm{GW}$ of panels per year as is given by multiplying the profit rate on panels, ${ }^{\pi}$ by Q, which is the difference in the sales cost and manufacturing cost or the difference between equations 3 and 4 :

$$
C_{n}=\pi \times Q=S_{n}-M_{n}
$$

Finally, the tax revenues can be calculated from personal income, corporate income and sales respectively from equations 1 to 5 to give:

$$
\begin{gathered}
T_{P, n}=t_{P, n} P_{n} \\
T_{C, n}=t_{C, n} C_{n} \\
T_{S, n}=t_{S, n} S_{n}
\end{gathered}
$$

The revenue saved from offsetting coal-fired pollution annually is calculated accounting for energy growth rate and inputting total solar energy generated as:

$$
H_{n}=h_{n} \times(1-g) \times E
$$

Cumulative offsetting is not considered for the previously deployed panels as the analysis assumes new revenue savings from the annual effort. This allows for a more conservative analysis. 
To assess the government investment for various scenarios, the government revenues estimated here will be treated as the cash inflows for the "government project", whilst any government investment or expenditure will be considered the cash outflows. The basic equations for the financial analysis to provide $I R R$ and payback period are given by equations 10 to 14 (Zerbe and Bellas, 2006). The net cash flow for a given year, $n$, is given by:

$$
C_{n e t, n}=C_{i n, n}-C_{o u t, n}
$$

Where

$$
C_{i n, n}=T_{P, n}+T_{C, n}+T_{S, n}+H_{n}
$$

which can be calculated from equations $6,7,8$, and 9 .

Finally, the $I R R$ and payback period can be found once the yearly net cash flows are determined. The $I R R$ of the project is considered the discount rate at which the net benefits and costs (or net cumulative cash flows) equal zero. It is also considered the break even interest rate and is compared against other project IRRs or an organization's minimum acceptable rate of return to determine which project is most viable (Zerbe and Bellas, 2006; Pearce et al., 2009). Thus interest rate is replaced by $I R R$ and found by iteration using:

$$
0=\sum_{n=0}^{N} \frac{C_{n e t, n}}{(1+I R R)^{n}}
$$

This can be calculated for different scenarios. The IRRs were calculated for different $N$ as 5, 10, 15 and 20 years to see the length of time needed for the investment to be considered most feasible. It is expected that the IRRs will increase as more years are considered because the cash inflows will increasingly dominate the cash outflow or investment. The less useful, but often used (Peace et al, 2009) payback period or $N_{P C F}$ is the first year that the cumulative cash flows for the project are positive and is calculated using: 


$$
0=\sum_{n=0}^{N_{P C F}} C_{n e t, n}
$$

\subsubsection{Other Benefits not Quantified}

\{Reconsider this section as per reviewer comments \}The study does not include the benefits of achieving internationally agreed political aims as a result of meeting emissions targets which would improve Canada’s global standing. The increased economic activity, including labour income, corporate profits, and interest and investment income (Abel et al., 2006), would increase Gross Domestic Product (GDP) which is not quantified here. Beyond meeting domestic demand, international PV exports could impact Canadian net exports (NX) which would increase the current account balance (CA) for the Canadian Economy (Abel et al., 2006). Multiplier effects were not considered for dollar value economic impacts. There is considerable uncertainty in estimating these values (DoF, 2009) but future work could entail more detailed economic impact models of investing in the solar PV manufacturing plants. Whilst these benefits can be said of any investment, the choice of investment must balance overall costs and benefits to society. For example, compared to other energy generation, PV production and installation impact the labour sector the most (Wei et al., 2010). As investment is not the only important concern for economic stability, it should not be considered individually infinitely into time. Sustainable development strategy will dictate the rates of investment in RETs as suggested by Kenny et al. (2010).

\subsection{Results}

Table 5 and 6 summarize the government revenues as outlined in Sec. 4.1 for Ontario and Canada respectively for 20 years using the estimates and equations discussed. All amounts are in 
Published as: K. Branker and J. M. Pearce, "Financial Return for Government Support of Large-Scale Thin-Film Solar Photovoltaic Manufacturing in Canada”, Energy Policy 38, pp. 4291-4303 (2010).

http://dx.doi.org/10.1016/j.enpol.2010.03.058

current \$ CAD. The total sum again represents the annual cash inflows for further analysis in each

scenario outlined in Sec. 5.

Table 5: Provincial Government Revenue Streams from $1 \mathrm{GW}$ plant for 20 years

\begin{tabular}{cccccccc}
\hline & & & \multicolumn{5}{c}{ Provincial Government Revenue (current \$CAD) } \\
\hline Year & Year & Phase & $\begin{array}{c}\text { Income } \\
\text { Tax }\end{array}$ & $\begin{array}{c}\text { Corporate } \\
\text { Income Tax }\end{array}$ & $\begin{array}{c}\text { Sales } \\
\text { Tax }\end{array}$ & $\begin{array}{c}\text { HEE costs } \\
\text { saved }\end{array}$ & Total \\
\hline 2009 & 0 & Construction & $\$ 3,406,208$ & $\$ 0$ & $\$ 0$ & $\$ 0$ & $\$ 3,406,208$ \\
2010 & 1 & Construction & $\$ 3,406,208$ & $\$ 0$ & $\$ 0$ & $\$ 0$ & $\$ 3,406,208$ \\
\hline 2011 & 2 & Ramp Up & $\$ 111,879,123$ & $\$ 0$ & $\$ 0$ & $\$ 0$ & $\$ 111,879,123$ \\
\hline 2012 & 3 & Operation & $\$ 111,879,123$ & $\$ 89,000$ & $\$ 160,000$ & $\$ 138,371,310$ & $\$ 250,499,433$ \\
2013 & 4 & Operation & $\$ 111,879,123$ & $\$ 89,000$ & $\$ 160,000$ & $\$ 136,572,483$ & $\$ 248,700,606$ \\
2014 & 5 & Operation & $\$ 111,879,123$ & $\$ 89,000$ & $\$ 160,000$ & $\$ 134,797,041$ & $\$ 246,925,164$ \\
2015 & 6 & Operation & $\$ 111,879,123$ & $\$ 89,000$ & $\$ 160,000$ & $\$ 133,044,679$ & $\$ 245,172,802$ \\
2016 & 7 & Operation & $\$ 111,879,123$ & $\$ 89,000$ & $\$ 160,000$ & $\$ 131,315,098$ & $\$ 243,443,222$ \\
2017 & 8 & Operation & $\$ 111,879,123$ & $\$ 89,000$ & $\$ 160,000$ & $\$ 129,608,002$ & $\$ 241,736,125$ \\
2018 & 9 & Operation & $\$ 111,879,123$ & $\$ 89,000$ & $\$ 160,000$ & $\$ 127,923,098$ & $\$ 240,051,221$ \\
2019 & 10 & Operation & $\$ 111,879,123$ & $\$ 89,000$ & $\$ 160,000$ & $\$ 126,260,098$ & $\$ 238,388,221$ \\
2020 & 11 & Operation & $\$ 111,879,123$ & $\$ 89,000$ & $\$ 160,000$ & $\$ 124,618,716$ & $\$ 236,746,840$ \\
2021 & 12 & Operation & $\$ 111,879,123$ & $\$ 89,000$ & $\$ 160,000$ & $\$ 122,998,673$ & $\$ 235,126,796$ \\
2022 & 13 & Operation & $\$ 111,879,123$ & $\$ 89,000$ & $\$ 160,000$ & $\$ 121,399,690$ & $\$ 233,527,814$ \\
2023 & 14 & Operation & $\$ 111,879,123$ & $\$ 89,000$ & $\$ 160,000$ & $\$ 119,821,494$ & $\$ 231,949,618$ \\
2024 & 15 & Operation & $\$ 111,879,123$ & $\$ 89,000$ & $\$ 160,000$ & $\$ 118,263,815$ & $\$ 230,391,938$ \\
2025 & 16 & Operation & $\$ 111,879,123$ & $\$ 89,000$ & $\$ 160,000$ & $\$ 116,726,385$ & $\$ 228,854,509$ \\
2026 & 17 & Operation & $\$ 111,879,123$ & $\$ 89,000$ & $\$ 160,000$ & $\$ 115,208,942$ & $\$ 227,337,066$ \\
2027 & 18 & Operation & $\$ 111,879,123$ & $\$ 89,000$ & $\$ 160,000$ & $\$ 113,711,226$ & $\$ 225,839,349$ \\
2028 & 19 & Operation & $\$ 111,879,123$ & $\$ 89,000$ & $\$ 160,000$ & $\$ 112,232,980$ & $\$ 224,361,103$ \\
2029 & 20 & Operation & $\$ 111,879,123$ & $\$ 89,000$ & $\$ 160,000$ & $\$ 110,773,951$ & $\$ 222,902,075$ \\
\hline
\end{tabular}

Table 6: Federal Government Revenue Streams from $1 \mathrm{GW}$ plant for 20 years

\begin{tabular}{ccccccc} 
& & & \multicolumn{4}{c}{ Federal Government Revenue (current \$CAD) } \\
\cline { 4 - 7 } Year & Year & Phase & Income & Corporate & Sales & \\
\hline 2009 & 0 & Construction & $\$ 8,151,936$ & $\$ 0$ & $\$ 0$ & $\$ 8,151,936$ \\
2010 & 1 & Construction & $\$ 8,151,936$ & $\$ 0$ & $\$ 0$ & $\$ 8,151,936$ \\
\hline 2011 & 2 & Ramp Up & $\$ 267,755,654$ & $\$ 0$ & $\$ 0$ & $\$ 267,755,654$ \\
\hline 2012 & 3 & Operation & $\$ 267,755,654$ & $\$ 150,000$ & $\$ 100,000$ & $\$ 268,005,654$ \\
2013 & 4 & Operation & $\$ 267,755,654$ & $\$ 150,000$ & $\$ 100,000$ & $\$ 268,005,654$ \\
2014 & 5 & Operation & $\$ 267,755,654$ & $\$ 150,000$ & $\$ 100,000$ & $\$ 268,005,654$ \\
2015 & 6 & Operation & $\$ 267,755,654$ & $\$ 150,000$ & $\$ 100,000$ & $\$ 268,005,654$ \\
2016 & 7 & Operation & $\$ 267,755,654$ & $\$ 150,000$ & $\$ 100,000$ & $\$ 268,005,654$ \\
2017 & 8 & Operation & $\$ 267,755,654$ & $\$ 150,000$ & $\$ 100,000$ & $\$ 268,005,654$ \\
2018 & 9 & Operation & $\$ 267,755,654$ & $\$ 150,000$ & $\$ 100,000$ & $\$ 268,005,654$ \\
2019 & 10 & Operation & $\$ 267,755,654$ & $\$ 150,000$ & $\$ 100,000$ & $\$ 268,005,654$ \\
2020 & 11 & Operation & $\$ 267,755,654$ & $\$ 150,000$ & $\$ 100,000$ & $\$ 268,005,654$ \\
2021 & 12 & Operation & $\$ 267,755,654$ & $\$ 150,000$ & $\$ 100,000$ & $\$ 268,005,654$ \\
2022 & 13 & Operation & $\$ 267,755,654$ & $\$ 150,000$ & $\$ 100,000$ & $\$ 268,005,654$ \\
2023 & 14 & Operation & $\$ 267,755,654$ & $\$ 150,000$ & $\$ 100,000$ & $\$ 268,005,654$ \\
2024 & 15 & Operation & $\$ 267,755,654$ & $\$ 150,000$ & $\$ 100,000$ & $\$ 268,005,654$ \\
2025 & 16 & Operation & $\$ 267,755,654$ & $\$ 150,000$ & $\$ 100,000$ & $\$ 268,005,654$ \\
2026 & 17 & Operation & $\$ 267,755,654$ & $\$ 150,000$ & $\$ 100,000$ & $\$ 268,005,654$ \\
2027 & 18 & Operation & $\$ 267,755,654$ & $\$ 150,000$ & $\$ 100,000$ & $\$ 268,005,654$ \\
2028 & 19 & Operation & $\$ 267,755,654$ & $\$ 150,000$ & $\$ 100,000$ & $\$ 268,005,654$ \\
2029 & 20 & Operation & $\$ 267,755,654$ & $\$ 150,000$ & $\$ 100,000$ & $\$ 268,005,654$ \\
\hline
\end{tabular}

\section{Government Return on Investment for Six Scenarios in Large Scale Thin Film PV}

\section{Manufacturing}


Six general scenarios were considered for government investment in solar thin film

manufacturing. The options for investment are not limited to these, and it is possible for combinations or variations of these scenarios to be used as considered appropriate. Sec. 2 detailed that the total cost of a $1 \mathrm{GW}$ fab is $\$ 2.4$ Billion. The different scenarios consider ways in which the Ontario and Federal governments can invest in the $1 \mathrm{GW}$ thin film PV facility. From Sec. 4, Table 5 and 6 summarized the government revenues for Ontario and Canada respectively for 20 years with the total sum representing annual cash inflows for the analysis in the scenarios.

It is assumed in this paper that once the IRR is above 8\%, the investment is viable ignoring inflation. For social aims such as improving health and environment, the social discount rate can be lower than 8\%, even as low as 3\% real (Jenkins and Kuo, 2007; TBC, 2007) or approximately 5\% with $2 \%$ inflation, making the assumption acceptable. However, it is important to note that once the plant continues to exist and produce profitable and sustainable business, the government will indefinitely continue to gain revenue generated by taxation and the respective IRRs will continue to increase. The major risk is default of the plant due to insolvency and thus not generating the expected revenue streams. Proper market research, a standardized turnkey facility and appropriate company management minimize or mitigate this risk. The company risk is related to the amount of capital they have to invest in the project before gaining earnings. Thus, each scenario will consider how much the scenario aids the company towards its success. Table 7 summarizes the results for the six scenarios discussed in the following subsections.

\subsection{Scenario 1: $100 \%$ Subsidy of Construction and Give Away}

This case considers the government investing in the construction of the facility and then freely handing it over to some other company or party to run. Three options exist for this particular case. 
Either the provincial and federal governments invest equal amounts of $\$ 1.2$ billion each in the plant, or either one or the other invests the full amount. This investment is a cash outflow in year 0 for the analysis. Other apportioning between the two can be considered, but only these three will be detailed. When the other government does not invest, it gets the pure total revenue streams once the plant exists, and financial analysis is unnecessary.

The best option in this scenario is to share the investment (1a), where the payback is less than 7 years for both governments and the 10 year IRRs are greater than $8 \%$. It is common that the federal government matches provincial transfers and vice versa for beneficial social programs (Marchildon et al., 2006; Westhues, 2006). Whilst the government benefits from the plant, the company that operates the plant benefits from the initial upfront capital investment offset. This is helpful because companies do not have the same mechanisms for revenue generation through taxation from the plant as does the government.

This scenario option is considered the most drastic as it is not common business practice to "give away" a project. However, the indirect investment returns, should the project succeed under the operating company, can justify such an investment. The most conflicting views will come from tax payers that think it unwise for the government to give away a project and so proper political campaign and stakeholder involvement in the decision will be required. Political repercussions is the major challenge in the short term as people remember issues with the dismal economic performance of the subsidies surrounding Atomic Energy of Canada Limited (Adams, 2006; Kaihla, 1995).

\subsection{Scenario 2: Fund Construction and Sell to Private Bidders}

This scenario considered the government fully funding the construction of the 1 GW PV facility and then selling it to the highest bidder(s) to operate the plant. From Scenario 1, it is best for the federal 
and provincial governments to share the investment. It is assumed that the bid will be less than market price as companies did not do it themselves at cost. This total bid is arbitrarily chosen to be $\$ 2$ billion (a 17\% discount or a subsidy for the infrastructure not directly related to deposition) that is equally paid half - half to the provincial and federal governments in year 2 .

The payback for this scenario is even faster than in Scenario 1 as almost all of the investment in the plant is paid in one lump sum and both governments see a payback of less than 3 years. Since the payback period is less than 3 years, even the 5 year IRRs are vastly greater than $8 \%$. This analysis can be re-done for lower bids, but it is expected to show that the economic activity that generates taxation and HEE benefits will account for any short fall in the bidding price.

The benefit to the bidding company (or companies) is that they can invest less than market rate for an already constructed plant that is ready to generate revenue. This will provide savings in terms of the waiting period for their capital investment to start recovering itself by avoiding the wait for construction. This scenario is not as politically challenging because it would appear as though the government is partially subsidizing and selling the plant and regaining tax dollars, even though it would appear as if it was a loss if the bid is lower than the construction cost. None-the-less, it is akin to other government subsidies in several sectors (Taylor et al., 2005) that consider revenue earnings though economic activity.

\subsection{Scenario 3: Partially Subsidize Construction with Funding Program}

An example of an appropriate funding program that can partially subsidize construction is the Next Generation of Jobs Fund (NGJF) (IO, 2009a). The fund will provide up to 15\% of the total eligible costs of a project in the form of a conditional grant. However, the ministry may also consider requests for funding in the form of loan (a low interest rate loan, a forgivable interest loan, or a 
forgivable loan) on a case by case basis allowing for higher investment. Other funds could be considered for this scenario beyond this example. There are two options under this scenario. The first (3a) is the NGJF alone under the provincial government, and the second (3b) is if the federal government matched the NGJF amount. Thus the investment in 3a is $15 \%$ of $\$ 2.4$ billion or $\$ 360$ million from Ontario and the investment in $3 \mathrm{~b}$ is the same for the province, but matched with a federal investment of $\$ 360$ million in the same year.

As expected, because the investment is much smaller, the IRRs are much higher for both type 3 scenarios than those presented earlier. Scenario $3 \mathrm{~b}$ would be preferred as its gives greater assistance to the company running the plant. Again, there is a fast payback of less than 3 years for both governments. Again, because the payback is less than 3 years, the 5 year IRRs are vastly greater than $8 \%$. Since this option is easy to implement and observes fast returns, the governments may seek it as a safe option. However, the clear returns in Scenario 1a means that even a drastic approach can work giving greater assistance to the company, and reducing its chance of business failure. This method of government investment in the PV sector is used in many countries throughout the globe.

\subsection{Scenario 4: Publicly Owned Plant}

This scenario entails both governments equally investing $\$ 1.2$ billion each in the plant, and then having the provincial government run the plant. This investment is a cash outflow in year 0 for the analysis. However, increased costs are added to the provincial government or a subsidiary which assumes running cost to be the direct salaries and the cost of manufacturing. Thus in this scenario the sale of the panels themselves are at cost - and a direct subsidy to PV consumers. It is also assumed that no corporate taxes are paid as a publicly owned company. 
As expected, the payback for the provincial government is much longer than for the federal government because of the additional expense of operating the plant, but it is still less than 10 years.

The 20 year IRR is again over $8 \%$. The federal government on the other hand sees a faster payback of less than 6 years and a high 10 year IRR of almost 14\%. This is a possible option, but careful consideration must be made to do appropriate research and development to remain competitive in the solar PV market. Obviously the more economically advantageous position could also be taken where the government facility sells panels at a small profit to ensure an appropriate IRR.

\subsection{Scenario 5: Loan Guarantee for a company to build and run the plant}

This scenario considers the government providing a loan guarantee for the company to invest in the $1 \mathrm{GW}$ plant. Two options are considered: $5 \mathrm{a}$ - the company defaults on the loan in year 5 and the governments equally share the loan payment and helps bail out the company from closure, and $5 b$ - the company does not default and it is as if the government did not have to invest anything. For 5a, a cash outflow of $\$ 1.2$ billion is considered for each government not considering interest on the loan in year 5 . These scenario descriptions are appropriate since loan guarantees are not charged against the government budget in the year they are granted, but the government is liable to any payments required in future years if there is a default (Baldwin, et al., 1983). Other governments have considered loan guarantees to attract solar manufacturing. For example in the Philippines, Sunpower was granted a \$200 million loan guarantee with a 6 year tax holiday for a 150 MW solar manufacturing plant (SEIA, 2009).

Scenario 5a is not desirable as the payback is long and the returns given are only secured should the company still be able to continue running the plant once the government repays its loan. This is an undesirable option with enormous uncertainty. For scenario 5b, since the governments invest nothing in 
essence, then the IRR and payback cannot be calculated. However, both governments still gain the full

revenue streams from the plant functioning as given in Sec. 4. The benefit is securing a favourable loan for the company to support installing and running the plant. Other benefits of this type of assistance are not discussed further. It is recommended that government put aside the money guaranteed in case of default and monitor the company's progress to estimate the probability of default accurately (Baldwin et al., 1983).

\subsection{Scenario 6: Income Tax Holiday}

This scenario considers offering the solar manufacturing company a corporate income tax holiday for 15 years. This is similar to the 15 year tax holiday offered in Malaysia that attracted four of First Solar's manufacturing facilities (CIOL, 2008; SEIA, 2009). Thus the plant would not have to pay corporate income tax for 15 years, reducing its operating costs. This is modeled by changing the corporate income tax rate to $0 \%$. It is therefore considered that the government invested the foregone corporate taxes in year 0 and the company benefits from reduced operating costs. Places like the Philippines have combined the income tax holiday with a loan guarantee, carbon credit tax exemptions and duty free importation of renewable energy equipment (Pérez, 2009; SEIA, 2009).

For this scenario, the IRR and payback cannot be calculated since the foregone corporate tax represents a negligible investment compared to the cost of the plant and other government revenue streams. The total foregone corporate tax is $\$ 1,335,000$ for the province and $\$ 2,250,000$ for Canada in this analysis. This represents a very small investment for the government, but equally small assistance for the company, perhaps negligible on its own without other production stimuli and incentives from the government. 


\subsection{Summary of Results and Analysis}

Table 7 summarizes the results for the six scenarios discussed above.

Table 7: Summary of the IRR and paybacks to the Provincial (Ontario) and Federal governments for the six scenarios

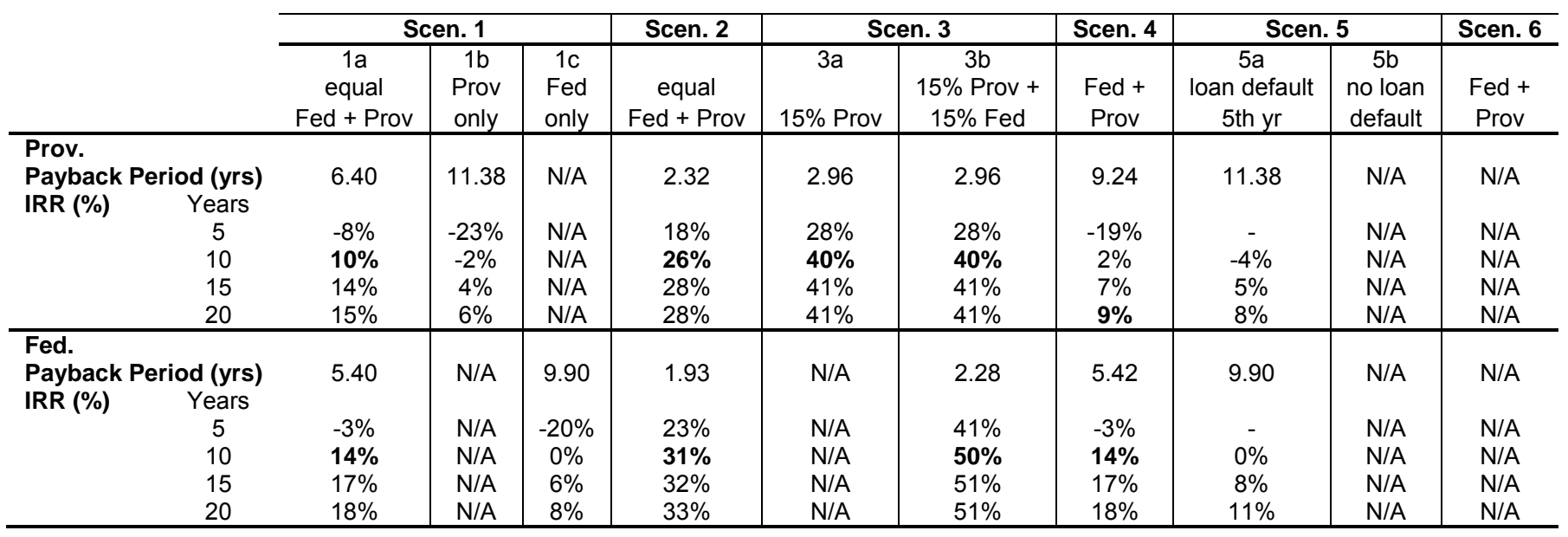

Scenarios 1b, 1c and 5a are not desirable from a government stand point limited to an $8 \%$ IRR. In Scenario 5b, no loan default means the government invests nothing, but still has returns from the economic activity. The loan guarantee is helpful, but is not as beneficial to a company compared to actually directly investing. In Scenario 6, the tax holiday has little investment or loss for the government, but again has a negligible impact on the capital required for the project from the company perspective. Scenario $3 \mathrm{~b}$ is better than $3 \mathrm{a}$ as it helps the company more, with both governments easily able to recover the investment though economic activity. Scenario 1a, although aggressive, shows that it is possible for the government to give away the project whilst gaining a high return. Scenario 2 is more acceptable politically and commercially, but does not help the company decrease its upfront investment, though it reduces the lead time towards regaining revenue through sales. Lastly, Scenario 4, where the government publicly owns the project, even though it has a lot lower returns due to the fact that the provincial government needs to fund the operating costs as well and is giving the panels 
Published as: K. Branker and J. M. Pearce, "Financial Return for Government Support of Large-Scale Thin-Film Solar Photovoltaic Manufacturing in Canada”, Energy Policy 38, pp. 4291-4303 (2010).

http://dx.doi.org/10.1016/j.enpol.2010.03.058

away at cost, it is still able to see reasonable returns and may even get assistance from the federal government.

As the scenarios where the governments are not making direct financial investments in the plant the IRR cannot be calculated, but it is instructive to consider the cash flows in these scenarios compared to the more traditional 'investment' scenarios. Figure 2 and 3 show the cumulative revenue streams for both governments. Note the revenue streams are higher with less investment. The trade off of helping the company must be considered however, as the aim is to attract a solar PV company that can prosper and therefore generate the revenue streams. Note that the change in cash flow for Scenario 2 is where the company pays the government for the plant and the change in Scenario 5a shows a company defaulting on the loan guarantee such that the government has to bear the burden.

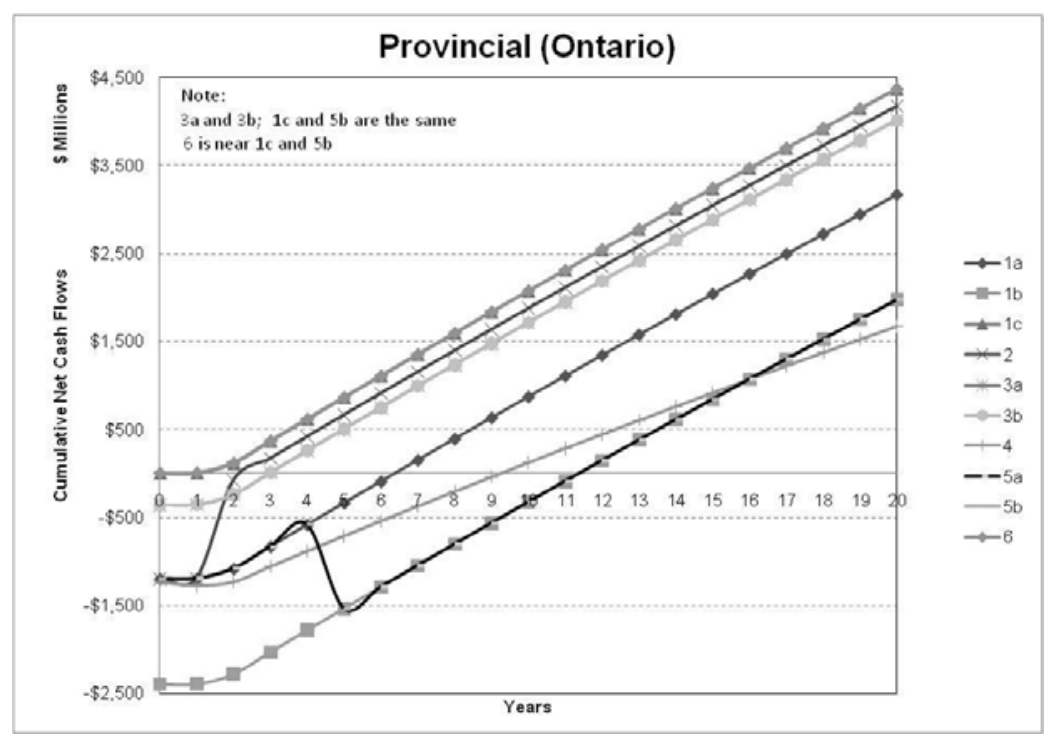

Figure 2. The cumulative cash flows for Provincial Government in the 6 scenarios. 


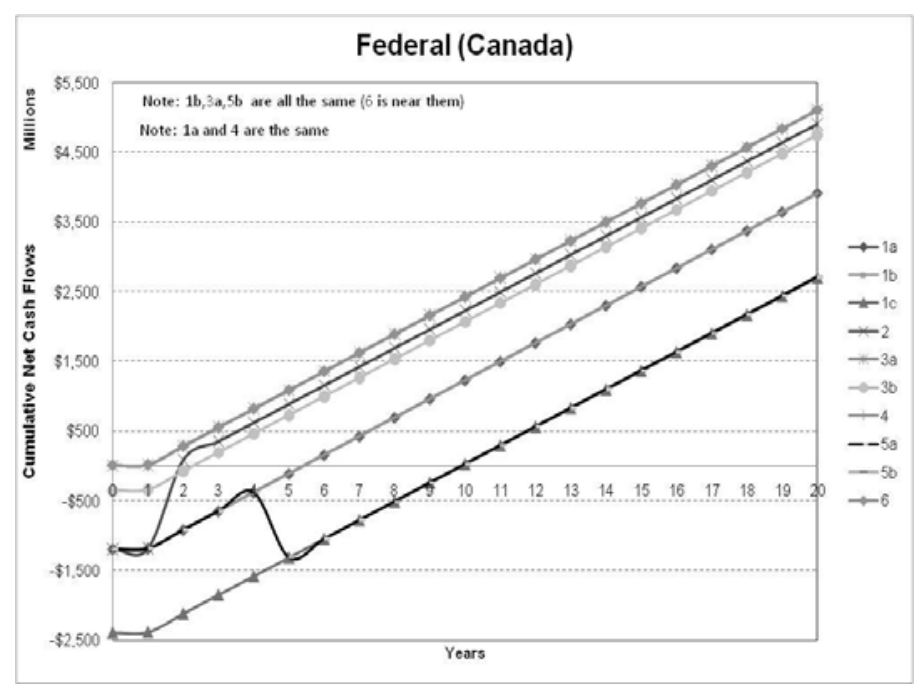

Figure 3. The cumulative cash flows for Federal Government in the 6 scenarios.

\subsection{Single Variable Sensitivity Analysis}

A single variable sensitivity analysis was conducted on 8 input variables to understand the effect of changes when related to the 10 year IRR calculation. As such, each input variable was changed within a plus or minus percentage margin and the effect of the change on the IRR was calculated. This was only done for scenario (1a) to gain an understanding of the effect of changes. Because the relationships were near linear, a general dependence could be estimated by calculating the slope of the trend lines generated. Thus a slope is the ratio of the change in the IRR over the change in the variable. Table 8 summarizes the general dependence of the variables and illustrates the difference in dependence between provincial and federal investment.

\begin{tabular}{lcc}
\begin{tabular}{l} 
Table 8: $\begin{array}{c}\text { Sensitivity of Project IRR in Federal and Provincial } \\
\text { Governments to } 8 \text { inputs variables }\end{array}$ \\
\cline { 2 - 3 }
\end{tabular} & \multicolumn{2}{l}{ IRR dependence } \\
\cline { 2 - 3 } & Prov & Fed \\
\hline Factor & 1.0 & 1.6 \\
\hline Income Tax Rate & 0.0 & 0.0 \\
Corporate Income Tax Rate & 0.0 & 0.0 \\
Construction Jobs & 1.0 & 1.6 \\
Operation Jobs & 1.0 & 1.7 \\
Wages & 1.0 & 0.0 \\
Coal Offset (HEE costs) & -0.3 & -0.2 \\
Inflation & 0.0 & 0.0 \\
Manufacturing Costs & & \\
\hline
\end{tabular}


In Table 8, a 1.0 for example represents a proportional relationship, such that a $10 \%$ increase in the factor represents a $10 \%$ increase in the IRR. A 0.0 means there is negligible dependence on the variable. In the case of inflation, the negative sign means an opposite relationship such that and increase in inflation leads to a decrease in IRR. Thus -0.3 means a $10 \%$ increase in inflation results in a 3\% decrease in IRR. Lastly, 1.6 means $10 \%$ change in the variable results in $16 \%$ change in IRR. In general, changes have a bigger effect on the federal budget than the provincial for income, number of jobs and wages. There is a negligible effect from corporate tax, construction jobs and manufacturing cost. Inflation has a medium effect, but larger effect on the provincial government than the federal government. The coal offset shows no change for fed in this analysis, but changes for province, as expected with the assumption. Sensitivity was not done on the energy growth rate, sales tax, and selling price (thus profit margin) as they are stable variables. A limitation of the single variable analysis is that it does not represent what the combined effect of variables on both governments would be, but as this would increase the complexity and number of calculations required it is left for future work.

\section{Discussion}

In general, the lower the investment from the governments in a $1 \mathrm{GW}$ PV plant, the greater the returns and the lower the risk. However, this does not support the most likely success of the PV plant. It was concluded from Scenarios 1 and 3, that the best way to invest in the plant would entail a joint investment from both the provincial and federal governments. Whilst the loan guarantee (5) and income tax holiday (6) presented the lowest investment from the government, it did not assist the plant's future success enormously. In the case of the plant's loan default, the government would have the burden for the loan guarantee. Again, the low capital assistance that scenario 5 and 6 present would increase the probability of the company's failure or more likely the lower probability of a plant locating 
Published as: K. Branker and J. M. Pearce, "Financial Return for Government Support of Large-Scale Thin-Film Solar Photovoltaic Manufacturing in Canada”, Energy Policy 38, pp. 4291-4303 (2010).

http://dx.doi.org/10.1016/j.enpol.2010.03.058

in Ontario. Having a publicly owned plant (4) would ensure reasonable returns for both governments, even with the additional operating expense, but due diligence is required to ensure the plant remains abreast of emerging technologies to remain competitive in the global solar industry. Considering the growing market share of government owned energy industries, government ownership in this sector does not necessarily in anyway impede technical innovation and in fact through careful support of research and development through the Ontario Centers of Excellence and the Natural Science and Engineering Research Council in Canada could increase the rate of PV-technical evolution. Fully subsidizing the plant and handing it over to a company (1a) or fully constructing the plant and selling by bidding (2) enables greater assistance for a company that has vast experience in the solar industry or its technology, but limited capital to deploy a $1 \mathrm{GW}$ plant, whilst gaining a high return in benefits for both governments. This would bode well for the success of the company and the economy with the capital support of the government. There are already programs in place to utilize Scenario 3 and it is clear these programs could be allowed to be far more generous for the PV industry while still earning an acceptable financial return. The sensitivity analysis demonstrates the robustness of the assumptions and analysis because large (doubling) trends are not observed in the dependence of the IRRs.

It is the aim of this paper to provide these results as a guide to fiscal policy and investment. Providing support for PV manufacturing would assist sustainable economic development and help with RET directives for provincial content in the FIT program in Ontario (OPA, 2009). It is within the government's role to invest in benefits to society. The amount of investment required for a large scale PV manufacturing plant (currently $\$ 2.4$ billion for $1 \mathrm{GW}$ ) is within the scale of usual government expenditures. In December 2008, Canada and Ontario provided \$4 billion in short term repayable loans to GM and Chrysler, with \$2.7 billion from the Government of Canada (DoF, 2009). Examples of 
Published as: K. Branker and J. M. Pearce, "Financial Return for Government Support of Large-Scale Thin-Film Solar Photovoltaic Manufacturing in Canada”, Energy Policy 38, pp. 4291-4303 (2010).

http://dx.doi.org/10.1016/j.enpol.2010.03.058

Canadian government subsidies include $\$ 3$ to $\$ 8$ billion in the forestry industry, $\$ 6$ billion in the mining industry, and at least $\$ 1.5$ billion in oil and gas industry annually (Taylor et al., 2005).

In basic economic theory, comparative advantage suggests that countries specialize in producing goods and services for which they have higher productivity and technological capacity (Ragan and Lipsey, 2007). Thus some economists would argue that Canada should not compete against well established industries in the global solar PV industry. As outlined before, the promise of turnkey manufacturing plants is standardization of manufacturing technology, which grants access to all players in the industry regardless of location. Despite being smaller than Canada, Germany has become the world leader in solar PV and wind technology, having had long established renewable energy policy directives (EPIA, 2008; Peters and Weirs, 2008). Canada could reach a comparable productivity with appropriate incentives. Canada is already developing strong renewable energy directives (Smitherman, 2009) and manufacturing continues to be a large part of its economy representing one sixth of Canada's GDP (Baldwin and MacDonald, 2009; IC, 2009; StatCan, 2009b). The Government of Canada is improving and adapting the manufacturing and processing sector with new polices for taxation; energy; trade; labor; intellectual property rights protection; regulations; infrastructure and research, development and commercialization to enhance the foundation of sustainable long term economic growth (Baldwin and MacDonald, 2009; DoF, 2009). Ontario offers a skilled and diverse workforce, a socialized healthcare system, government commitment to innovation and economic growth, internationally competitive wage and tax rates and globally competitive labor costs and benefits (IO, 2009b). The proven technology of thin film PV combined with the financial and manufacturing stability of Ontario, Canada augur well for government investment in PV manufacturing and its success at generating economic activity, and, social and environmental benefits for the country. The choice of 
entering this market is the consideration between creating domestic economic activity and subsidizing economic activity in other countries via imports because the FIT $^{7}$ will stimulate demand (Peters, 2008).

The financial analysis presented here is a basic estimation of the benefits of government support of large scale PV manufacturing in Canada. It is recommended that a more detailed study be considered for the accurate forecasting of the cash flows and risks stated here, taking into account other economic variables not included in the analysis presented.

\section{Conclusions}

Sustainable large scale manufacturing and achieving economies of scale with proper fiscal policy and government assistance will help solar PV reach grid parity. In order to accelerate the production of inexpensive renewable electricity governments in general and those of Ontario and Canada in particular can support large-scale PV manufacturing through incentives. This paper provided a financial analysis of a $1 \mathrm{GW} /$ year turnkey a-Si PV manufacturing plant, although the analysis could be replicated for other solar technology or RETs. The economic benefits for the provincial and federal governments were quantified for various levels of support of the PV manufacturing plant in Ontario from simple loan guarantees and tax holidays to more aggressive $100 \%$ subsidies. In all scenarios the governments enjoyed positive cash flows in less than 12 years and in many of the scenarios both governments earned IRRs well over $8 \%$ in short time periods. The results showed that it is in the financial best interest of both the Ontario and Canadian federal governments to implement aggressive policy to support PV manufacturing. Such policy would provide substantial economic, environmental and social benefits.

\section{Acknowledgments}


Published as: K. Branker and J. M. Pearce, "Financial Return for Government Support of Large-Scale Thin-Film Solar Photovoltaic Manufacturing in Canada”, Energy Policy 38, pp. 4291-4303 (2010).

http://dx.doi.org/10.1016/j.enpol.2010.03.058

The authors would like to acknowledge helpful discussions with and useful comments from Glenn Jenkins and Emmanuel Asinas and support from the Natural Sciences and Engineering Research Council of Canada. 


\section{References}

Abel, A. B., Bernanke, B.S., Kneebone, R. D., Smith, G. W., 2006. Macroeconomics, $4^{\text {th }}$ Canadian edition, Addison-Wesley Educational Publishers, Inc: Boston.

Adams, T., 2006. Federal Government Subsidies to Atomic Energy of Canada Limited, Energy Probe International, January 11, 2006, 1-8.

Alley , R. B., Marotzke, J. , Nordhaus, W. D., Overpeck, J. T., Peteet, D. M. , Pielke, R. A. Jr., Pierrehumbert, R. T. , Rhines, P. B. , Stocker, T. F. , Talley, L. D., Wallace J. M., 2003. Abrupt Climate Change. Science 299 (5615), 2005-2010.

Ayoub, J., 2007. Co-operative Programme on Photovoltaic Power Systems, National Survey Report of PV Power Applications in Canada 2006. International Energy Agency (IEA), May 2007, 1-21. Babinet, O., Gellman, D., Trkulja, J., Schneider, P., 2009. Solar’s Push to Reach the Mainstream. Deloitte Review, July 28, 2009.

Baldwin, C., Lessard, D., Mason, S., 1983. Budgetary Time Bombs: Controlling Government Loan Guarantees. Canadian Public Policy, 9(3), 338-346.

Baldwin, J. R., MacDonald, R. 2009. The Canadian Manufacturing Sector: Adapting to Challenges. Economic Analysis (EA) Research Paper Series, July, 2009, Minister of Industry: Ottowa.

Boyd, D.R., Genuis, S. J., 2008. The environmental burden of disease in Canada: Respiratory disease, cardiovascular disease, cancer, and congenital affliction. Environmental Research 106, 240_ 249.

Campbell, B., Dufay, L., Macintosh, R., 1997. Comparative Analysis of Employment from Air Emission Reduction Measures. Environment Canada - Global Air Issues Branch, January 31, 1997, The Pembina Institute for Appropriate Development: Drayton Valley. 
Canadian Electricity Association (CEA), 2009a. Electricity in Canada, Demand, Supply and Capacity, Accessed 20 August, 2009. Available at http://canelect.ca/en/electricityincanada/electricity_in_canada_snapshot_Demand_2009.html

Canada Electricity Association (CEA), 2009b. Electricity Generation in Canada by Province and Fuel Type, 2008, Accessed 20 August, 2009. Available at http://67.212.84.179/canelect.php?lang=en

Canada Revenue Agency (CRA), 2009. Corporate Tax Rates. 16-06-2009, Accessed 20 August, 2009. Available at http://www.cra-arc.gc.ca/tx/bsnss/tpcs/crprtns/rts-eng.html

Canadian Medical Association (CMA) 2008. No Breathing Room - National Illness Costs of Air Pollution. August 2008, 1-45.

Clean Air Online (CAO), 2009. Coal and Oil Fired Power, Environment Canada, Accessed 20 August, 2009. Available at http://www.ec.gc.ca/cleanair-airpur/Coal_and_Oil_Fired_PowerWS36F53482-1_En.htm

Collins, R. W., Ferlauto, A.S., Ferreira, G.M., Chen, C., Koh, J., Koval, R.J., Lee, Y., Pearce, J.M., Wronski, C. R., 2003. Evolution of microstructure and phase in amorphous, protocrystalline, and microcrystalline silicon studied by real time spectroscopic ellipsometry. Solar Energy Materials and Solar Cells 78(1-4), 143-180.

CyberMedia India Online Ltd. (CIOL), 2008. First Solar's first of four solar plants in Kedah, July 28, 2008, Accessed 20 August, 2009. Available at http://www.ciol.com/Semicon/SemiPipes/News-Reports/First-Solars-first-of-four-solar-plantsin-Kedah/28708108360/0/ 
Department of Finance (DoF), Canada, 2009. Canada’s Economic Action Plan, Budget 2009. January $27^{\text {th }}$, 2009, Public Works and Government Services Canada, Ottawa. Available at http://www.budget.gc.ca/2009/pdf/budget-planbugetaire-eng.pdf

Department of Finance (DoF), Canada, 2010. Canada’s Economic Action Plan Year 2, Budget 2010, Leading the Way on Jobs and Growth. March $4^{\text {th }}$, 2010, Public Works and Government Services Canada, Ottawa. Available at http://www.budget.gc.ca/2010/pdf/budgetplanbudgetaire-eng.pdf

DSS Management Consultants Inc. and RWDI Air Inc., 2005. Cost Benefit Analysis: Replacing Ontario's Coal-Fired Electricity Generation, Prepared for the Ontario Ministry of Energy.

Eikelboom, J.A. and Jansen, M.J. 2000. Characterisation of PV Modules of New Generations, ECN Report ECN-C-00-067.

European Photovoltaic Industry Association (EPIA) and Green Peace, 2008. Solar Generation V 2008 Report. EPIA Secretariat Offices Renewable Energy House: Brusells.

Faithful and Gould, (Project Consultants), 2007, Renewable Energy Corporation - Solar Manufacturing Complex, Accessed 20 August, 2009. Available at http://www.fgould.com/asia/projects/renewable-energy-corporation-solar-manufacturing/ Ferlauto, A.S., Ferreira, G. M., Koval, R. J., Pearce J. M., Wronski, C. R., Collins, R. W., Al-Jassim, M. M., Jones, K. M., 2004. Evaluation of Compositional Depth Profiles in Mixed Phase (Amorphous + Crystalline) Silicon Films from Real Time Spectroscopic Ellipsometry. Thin Solid Films 455-456, 665-669. 
First Solar, 2009. First Solar Passes $\$ 1$ Per Watt Industry Milestone, Feb. $24^{\text {th }} 2009$ (Press Release), Accessed 20 August, 2009. Available at http://investor.firstsolar.com/phoenix.zhtml?c=201491\&p=irol-newsArticle\&ID=1259614

Gordon, K., Hays, J., Sompolinsky, L., Tan, E., Tsou, J., 2007. Community Jobs in The Green Economy. Apollo Alliance and Urban Habitat: San Francisco.

Green Energy and Green Economy Act, 2009. Bill 150 Available at http://www.ontla.on.ca/web/bills/bills_detail.do?locale=en\&BillID=2145

Hayami, H., Nakamura, M., 2007. Greenhouse gas emissions in Canada and Japan: Sector-specific estimates and managerial and economic implications. Journal of Environmental Management 85 (2007) 371-392.

Industry Canada (IC), 2009. Manufacturing: Moving Forward — Rising to the Challenge, The Government Response to the Fifth Report of the House of Commons Standing Committee on Industry, Science and Technology. April, 2009. Available at http://www.ic.gc.ca/eic/site/ic1.nsf/eng/h_02860.html

Intergovernmental Panel on Climate Change (IPCC), 2008. Climate Change 2007: Synthesis Report. Intergovernmental Panel on Climate Change. Cambridge University Press, Cambridge, United Kingdom.

International Energy Agency (IEA), 2008. Energy Technology Perspectives 2008: Scenarios and Strategies to 2050. International Energy Agency, IEA/OECD, Paris, France.

Invest in Ontario (IO), 2009a. Next Generation of Jobs Fund - Jobs \& Investment Program - Ministry of Economic Development and Trade, Accessed 20 August, 2009. Available at http://www.investinontario.com/resources/government_programs_progdetails.asp?pID=215 
Invest in Ontario (IO), 2009b. Why Ontario, Accessed 20 August, 2009. Available at http://www.investinontario.com/whyontario/default.asp

Jardine, C.N., Conibeer, G. J. and Lane, K., 2001. PV-COMPARE: Direct Comparison of Eleven PV Technologies at Two Locations in Northern and Southern Europe. Proceedings of the $17^{\text {th }}$ European PVSEC, Munich 2001, VD1-13.

Jenkins, G., Kuo, C. 2007. The Economic Opportunity Cost of Capital for Canada—An Empirical update. QED, Working Paper Number 1133, Department of Economics, Queen’s University, Kingston, Canada, 1-25.

Kaihla, P., 1995. A troubled nuclear family. Maclean's, 108 (32), 24-26.

Kenny, R., Law, C., Pearce, J.M., 2010.Towards Real Energy Economics: Energy Policy Driven by Life-Cycle Carbon Emission, Energy Policy 38, 1969-1978

Keshner, M.S., Arya, R., 2004. Study of potential cost reductions resulting from super-large-scale manufacturing of PV modules. National Renewable Energy Laboratory, final subcontract report, NREL/SR-520-36846.

Kumar, S., Bommelear, A., Chan, A., Chen, E., Iltgen, K., 2007. Credit Suisse - Solar Market Review. 13 December, 2007, 1- 32.

Marchildon, G. P., Mossialos, E., Allin, S., 2006. Health systems in transition: Canada. European Observatory on Health Systems and Policies, University of Toronto Press Incorporated and WHO, pp. 1- 156 ( p.24)

National Energy Board (NEB), 2007. Energy Demand for Ontario, Projections to 2030 - Canada Energy Future Reference Case and Scenarios to 2030, An Energy Market Assessment November 2007, National Energy Board: Calgary. 
Neij, L., 2008. Cost development of future technologies for power generation—a study based on experience curves and complementary bottom-up assessments. Energy Policy 36(6), 22002211.

Nguyen, H.T. and Pearce, J.M., 2010. Estimating Potential Photovoltaic Yield with r.sun and the Open Source Geographical Resources Analysis Support System. Solar Energy (in press).

Office of the Premier of Ontario, 2009. McGuinty Government Progress Report - Energy, Available at http://www.premier.gov.on.ca/progress/en/energy.asp

Ontario Medical Association, OMA, 2005. Illness Costs of Air Pollution Report, June 2005.

Ontario Power Authority Feed In- Tariff (OPA), 2009.Accessed 20 August, 2009. Available at http://microfit.powerauthority.on.ca/Participating-in-microFIT/index.php

OPA, Ontario Power Authority (2009), Feed-in Tariff Program Development, Accessed 20 August, 2009. Available at http://www.powerauthority.on.ca/fit/Page.asp?PageID=1226\&SiteNodeID=1039

Ontario, 2010. NEWSROOM:Ontario Delivers \$7 Billion Green Investment, January 21st. Available at http://news.ontario.ca/mei/en/2010/01/backgrounder-20100121.html

Organization for Economic Cooperation and Development (OECD), 2009. OECD Annual Tax

Database - Personal Income Tax Rates, Taxation of Corporate and Capital Income and Value Added Taxes, Accessed 20 August, 2009. Available at http://www.oecd.org/document/60/0,3343,en_2649_34533_1942460_1_1_1_37427,00.html

Osborne, M., 2008. PV production: The dawn of the "gigawatt" fab. Solar Report. 08/11/2008, Accessed 20 August, 2009. Available at http://www.solarserver.de/solarmagazin/solarreport_0808_e.html

Pearce, J. M., 2002. Photovoltaics - A Path to Sustainable Futures. Futures 34 (7), 663-674. 
Pearce, J. M., 2008. Industrial Symbiosis for Very Large Scale Photovoltaic Manufacturing. Renewable Energy 33, 1101-1108.

Pearce, J. M., Denkenberger, D., Zielonka, H. 2009. Accelerating Applied Sustainability by Utilizing Return on Investment for Energy Conservation Measures. International Journal of Energy, Environment and Economics 17(1), 61-80.

Pérez ,V. S., 2009. Status of Renewable Energy Policy in the Philippines. Presented at Climate and Clean Energy Week: High-Level Dialogue on Climate Change in Asia and the Pacific, and the $4^{\text {th }}$ Asia Clean Energy Forum 2009.

Peters, R. and Weis, T., 2008. Feeding the Grid Renewably: Using feed-in tariffs to capitalize on renewable energy. The Pembina Institute: Drayton Valley.

Pinto, M. R., 2008. Has the sun finally risen on photovoltaics? Symposium on VLSI Technology, 2-5.

Public Health Agency of Canada, (PHA) 2009. Population Health Fund Evaluation 2008 Final Report, Accessed 20 August, 2009. Available at http://www.phac-aspc.gc.ca/about_apropos/reports/2008-09/phf-fsp/index-eng.php

Pollin, R., Garrett-Peltier, H., 2009. Building the Green Economy, Employment Effects of Green Energy Investments for Ontario, 1-32.

Ragan, C. T. S., Lipsey, R. G., 2007. Microeconomics, $11^{\text {th }}$ Canadian Edition, Pearson Addison Wesley.

REN 21, Renewable Energy Policy Network for the 21st Century. (2009). Renewable Energy Policy Network for the 21st Century. (2009). Renewables Global Status Report 2009 Update, Deutsche Gesellschaft füur Technische Zusammenarbeit (GTZ) GmbH, 1-32.

Rentzing, S. 2007. Geared up for Giga-demand. New Energy, 6/07, 50. 
Rosen, M.A., 2008. Minerva Canada Case Study: General Motors: Achieving and Maintaining WorldClass Leadership in Worker Health and Safety in the Automotive Industry, Minerva Canada.

Schachter, M., 1979. The Job Creation Potential of Solar and Conservation: A Critical Evaluation. The Department of Energy, Washington, D.C.

Schaeffer, G. J., Seebregts, A.J., Beurskens, L.W.M., Moor, H.H.C., Alsema, E.A, Sark, W., Durstewicz, M., Perrin, M., Boulanger, P., Laukamp, H., Zuccaro, C., 2004. Learning from the Sun, Analysis of the use of experience curves for energy policy purposes -The case of photovoltaic power. Final report of the Photex project.

Sims, R. E. H., Rogner, H., Gregory, K., 2003. Carbon emission and mitigation cost comparisons between fossil fuel, nuclear and renewable energy resources for electricity generation. Energy Policy 31, 1315-1326.

Smitherman, G., 2009. Bill 150, An Act to enact the Green Energy Act, 2009 and to build a green economy, to repeal the Energy Conservation Leadership Act, 2006 and the Energy Efficiency Act and to amend other statutes, 2009. Legislative Assembly of Ontario.

Solar Energy Industry Association, (SEIA), 2009. Solar Manufacturing Tax Credit, 12 January, 2009, Solar Energy Industry Association: Washington D.C.

Solarbuzz, 2009. Solarbuzz Reports World Solar Photovoltaic Market Grew to 5.95 Gigawatts in 2008. World PV Industry Report Summary, Accessed 20 August, 2009. Available at http://www.solarbuzz.com/Marketbuzz2009-intro.htm

Statistics Canada (StatCan), 2009a. Federal General Revenue and Expenditures, 2005-2009,Accessed 20 August, 2009. Available at http://www40.statcan.ca/101/cst01/govt02a-eng.htm Statistics Canada (StatCan), 2009b. Manufacturing sales, by province and territory,Accessed 20 August, 2009. Available at http://www40.statcan.gc.ca/101/cst01/manuf28-eng.htm 
Stern,N., 2007. The Economics of Climate Change: The Stern Review , Cambridge Univ. Press, Cambridge, UK.

Stoddard, L., Abiecunas, J., O'Connell, R., 2006. Economic, Energy, and Environmental Benefits of Concentrating Solar Power in California. National Renewable Energy Laboratory (NREL), May 2005 - April 2006, 1-69.

Taylor, A., Bramley, M., Winfield, M., 2005. Government Spending on Canada's Oil and Gas Industry, Undermining Canada's Kyoto Commitment. January 31, 2005, Commissioned by Climate Action Network Canada, The Pembina Institute: Drayton Valley.

Tolia, A., 2008. The Role of Industrial Gas Companies in Reducing Cost per Watt of Solar Cells. Presented at the Solar Materials, Equipment and Technology Conference (SMET), July 16, 2008.

Treasury Board of Canada (TBC), 2007. Canadian Cost-Benefit Analysis Guide: Regulatory Proposals. Treasury Board of Canada. Catalogue No. BT58-5/2007.

VLSI Research Inc., 2009. Photovoltaic Cell manufacturing equipment:Top-10 supplier ranking. Accessed 20 August, 2009. Available at https://www.vlsiresearch.com/cms_pdf_upload/pdf_file_1233694471.pdf

Wei, M., Patadia, S., and Kammen, D., 2010. Putting renewables and energy efficiency to work: how many jobs can the clean energy industry generate in the US? Energy Policy, 38 (2), 919-931.

Weinzerl, H., 2009. Oerlikon Solar Americas, Oerlikon Solar USA, Inc. Personal Communication, January 18, 2009.

Western Economic Diversification Canada (WEDC), 2008. Evaluation of the Western Diversification Program - Western Economic Partnership Agreements, December 2008, Accessed 20 August, 2009. Available at http://www.deo-wd.gc.ca/eng/11094.asp 
Published as: K. Branker and J. M. Pearce, "Financial Return for Government Support of Large-Scale Thin-Film Solar Photovoltaic Manufacturing in Canada”, Energy Policy 38, pp. 4291-4303 (2010).

http://dx.doi.org/10.1016/j.enpol.2010.03.058

Westhues, A., 2006. Canadian social policy: Issues and Perspectives, $4^{\text {th }}$ Edition, Wilfred Laurier University Press: Waterloo.

Wiginton, L.K., Nguyen, H.T. and Pearce, J.M., 2010. Quantifying Rooftop Solar Photovoltaic Potential for Regional Renewable Energy Policy, Computers, Environment and Urban Systems, (in press).http://dx.doi.org/10.1016/j.compenvurbsys.2010.01.001

Zerbe, R.O., Bellas, A.S., 2006. A Primer for Benefit-Cost Analysis, Edward Elgar Publishing. 


\section{Footnotes}

1. Personal communication with Helfried Weinzerl and Scott Graybeal at Oerlikon, 2009.

2. Demanding roughly $84 \mathrm{MW}$ per month. This is marginally higher than the presented ramp up of 65 MW per month given by the Linde Group (Tolia, 2008) but should be possible with the learning curve observed in the industry (Neij 2008; Pinto, 2008; Schaeffer et al., 2004).

3. The carbon dioxide reduction considers reduction from the entire energy mix. However, coal represents $73 \%$ of fossil fuel energy generation in Ontario such that coal offsetting can be assumed. Note that if the solar PV were used for direct coal offsetting, there would be a larger reduction in emissions, but reducing reductions as more solar came online.

4. South facing house with roof tilt angle of $45^{\circ}$. In addition the amount of $\mathrm{CO}_{2}$ reduced is variable as it will decrease as more solar panels become part of the electrical grid, but will increase as the supplies of readily available fossil fuels decreases.

5. $1 \mathrm{MW}$-hr = $1000 \mathrm{~kW}$-hrs, $1 \mathrm{GW}$-hr = $1000 \mathrm{MW}$-hrs, 1TW-hr=1000 GW-hr

6. Solar Energy (MW-hr/yr) = 1000 MW x 3 hrs/day x 365 days/ yr as 1 GW=1000 MW

7. The FIT program requires $40 \%$ provincial content which is meant to stimulate the local economic activity (OPA, 2009). 
Published as: K. Branker and J. M. Pearce, "Financial Return for Government Support of Large-Scale Thin-Film Solar Photovoltaic Manufacturing in Canada”, Energy Policy 38, pp. 4291-4303 (2010).

http://dx.doi.org/10.1016/j.enpol.2010.03.058

\section{Figure Captions}

Figure 1. Simple supply and demand schematic for growing the PV sector.

Figure 2. The cumulative cash flows for Provincial Government in the 6 scenarios.

Figure 3. The cumulative cash flows for Federal Government in the 6 scenarios. 